\title{
Intracoronary Adenosine Induced hyperaemia reduces the incidence of myonecrosis due to micro infraction after elective Percutaneous Coronary Intervention
}

\author{
MARAJIB ${ }^{1}$, MA SIDDIQUE $^{2}$, MK AHMED $^{3}$, KMHS S HAQUE $^{4}$, MM RAHMAN $^{5}$, F RAHMAN $^{6}$
}

(University Heart Journal 2007; 3 : 73-74)

Percutaneous Coronary Intervention (PCI) is associated with $5 \%$ to $30 \%$ incidence of elevation of serum Creatine Kinase MB fraction (CK-MB) reflect the periprocedural myonecrosis,' Appearance of Creatine Kinase MB (CK$\mathrm{MB})$ in the circulation is the strongest predictor of long term clinical outcome of $\mathrm{PCI}^{2-5}$, correlating the deleterious consequences of myonecrosis on Left Ventricular function or Electrophysiological stability ${ }^{6}$. Pathophysiology of myonecrosis during PCI has been related to side branch closure or compression, major intimal dissection, intramural thrombus formation, coronary spasm, distal atheroembolization. The first four causes may be clinically apparent and measures can be taken during the procedure, the latter may be entirely asymptomatic and occur even Angiographically uneventful procedure. Contrast enhanced Magnetic Resonance Imaging suggest that distal embolization of atherogenic materials from plaque disruption ${ }^{7}$, causing micro infarction by obstructing the blood flow at capillary level ${ }^{8,9}$.

Studies show that intra venous Adenosine infusion as an adjunct to reperfusion in the treatment of acute myocardial infarction associated with reduction of heart muscle damage ${ }^{10,11}$.

Adenosine is a naturally occurring nucleoside with a half life in blood of less than 10 seconds. Adenosine may be administered via intravenous or Intracoronary route, produce hyperemic effect that is commonly used to measure the coronary flow reserve during PCI. The

1. Dr. MA Rajib, MD Cardiology, Final Part Student, BSMMU

2. Prof. Md. Abu Siddique, Professor of Cardiology, UCC, BSMMU

3. Dr. Md. Khurshed Ahmed, Assistant Professor of Cardiology, UCC, BSMMU

4. Prof. KMHS Sirajul Haque, Professor \& Chairman, Dept. of Cardiology, UCC, BSMMU

5. Dr. Md. Mukhlesur Rahman, Assistant Professor of Cardiology, UCC, BSMMU,

6. Dr. Fazlur Rahman, Associate Professor of Cardiology, UCC, BSMMU

Address of correspondence : Dr. MA Rajib, MD Cardiology, Final Part Student, BSMMU, Dhaka mechanism of the cardio-protective effect of adenosine include preconditioning ${ }^{17}$, antiplatelet activity ${ }^{18}$, anti inflammatory effect ${ }^{19}$ and hyperamia ${ }^{20}$. There is a evidence from previous study that despite a short serum half life the cardio-protective effect the effect of Intracoronary adenosine infusion in human subjects persist much longer ${ }^{17}$.

Hyperaemic effect of Adenosine may be beneficial to ameliorate distal embolization of platelet thrombi following elective PCI. One study suggested that endogenous release of adenosine could compensate distal embolization of small particles ${ }^{21}$. The minimum dose is required to achieve minimum Fractional Flow Reserve (or maximum hyperaemia), 42 micro grams for both Left and Right Coronary artery in human without any significant side effect $^{22} .50$ micro grams bolus administration of adenosine through the guiding catheter before elective PCI to ameliorate distal embolization of relatively small platelet thrombi ${ }^{6}$, Although only a fraction of the administered adenosine would reach the target distal lesion, this above dosage (50 micro grams) and route of administration was sufficient to achieve maximum hyperaemia. Moreover, an Intracoronary bolus approach to administration, lower cost and reduce risk of bradycardia.

Adenosine induced hyperaemia can potentially ameliorates the deleterious effect of distal embolization associated with non-urgent elective Percutaneous Coronary Intervention (PCI) through dilatation of microvasculature. This may reduces capillary obstruction by facilitating the throughout passage of embolized platelet thrombi out to the venous end of coronary circulation, there by reduce the incidence of post procedural micro infraction and myonecrosis .

\section{References:}

1. Califf RM, Abdelmeguid AE, Kuntz RE, Popma JJ, Davidson CJ, Cohen EA, Kleiman NS, Mahaffey KW, Topol, Pepine CJ, Lipicky RJ, Granger CB, Harrington RA, Tardiff BE, Crenshaw BS, Bauman RP, Zuckerman BD, Chaitman BR, Bittl JA, Ohman EM.. Myonecrosis after revascularization procedures. JAm Coll Cardiol 1998; 3L241-251. 
2. Kini AS Lee P,Marmur JD, Agarwal A, Duffy ME, Kim MC, Sharma SK.Correlation of postpercutaneous coronary intervention creatine kinase-MB and troponin I elevation in predicting med-term mortality. Am J Cardiol 2004; 93: 18-23.

3. Brener SJ. Ellis SG, Schnerider J, Topol EJ. Frequency and long-term impact of myonecrosis after coronary stenting. Eur Heart J 2002; 23: 869-876.

4. Abdelmeguid AE, Topol EJ, Whitlow PL, Sapp SK, Ellis SG. Significance of mild transient release of creatine kinase- MB fraction after percutaneous coronary intervention. Circulation 1996; 94: 1528-1536.

5. loannidis JP, Karvouni E, Katritsis DG. Mortality risk conferred by small elevations of creatine kinase-MB isoenzyme after percutaneous coronary intervention. $\mathrm{JAm}$ Coll Cardio12003; 42: 1406-1411.

6. Ellis SG, Chew D, Chan A, Withlow PL, Schneider JP, Topol EJ. Death following creatine kinase- MB elevation after coronary intervention: identification of an early risk period: importance of creatine kinase- MB level, completeness of revascularization, ventricular function, and probable benefit of statin therapy. Circulation 2002; 106: 1205-1210.

7. Mehran R, Dangas G, Mintz GS, Lansky AJ, Pichard AD, Satler LF, Kent KM, Stone GW, Leon MB. Atherosclerotic plaque burden and CK- MB enzyme elevation after coronary intervention: intravascular ultrasound study of 2256 patients. Circulation 2000; 101: 604-610.

8. Ricciardi MJ, Wu E, Davidson CJ, Choi KM, Klocke FJ, Bonow RO, Judd RM, Kim RJ.Visualization of discrete microinfarction after percutaneous coronary intervention associated with mild creatine kinase- MB elevation. Circulation 2001; 103: 27802783.

9. Choi JW, Gibson CM, Murphy SA, Davidson CJ, Kim RJ, Ricciardi MJ. Myonecrosis following stent placement: association between impaired TIMI myocardial perfusion grade and MRI visualization of microinfarction. Catheter Cardiovasc Interv 2004; 61: 472-476.

10. Mahaffey KW, Puma JA, Barbagelata NA, DiCarli MF, Leesar MA, Browne KF, Eisenberg PR, Bolli R, Casas AC, MolinaViamonte V, Orlandi C, Blevins R, Gibbons RJ, Califf RM, Granger $\mathrm{CB}$. Adenosine as an adjunct to thrombolytic therapy for acute myocardial infarction: results of a multicenter, randomized, placebo- controlled trial: the acute myocardial Infraction study of adenosine (AMISTAD) trail. JAm Coll Cardiol 1999; 34: 1711-1720.

11. Ross AM, Gibbons RJ, StoneGW, Kloner RA, Alexander RW, AMISTAD-II Investigation. A randomized, double-blinded, placebo-controlled multicenter trial of adenosine as an adjunct to reperfusion in the treatment of acute myocardial infarction (AMISTAD- II). JAm Coll Cardiol 2005; 45: 1775- 1780.

12. Marzilli M, Orsini E, Maraccini P Testa R. Beneficial effects of intracoronary adenosine as an adjunct to primary angioplasty in acute myocardial infarction. Circulation 2000; 101: $2154-2159$.

13. Claeys MJ, Bosmans J, De Ceuninck M, Beunis A, Vargauwen W, Vorlat A, Vrints CJ. Effect of intracoronary adenosine infusion during coronary intervention on myocardial reperfusion injury in patients with acute myocardial infarction. Am J Cardiol 2004; 94: 9-13.

14. Reffelmann T, Kloner RS, The 'no-reflow' phenomenon: basic science and clinical correlates. Heart 2002; 87:162168.

15. Desmet WJ, Dens J, Coussement P, Van de Werf F. Does adenosine prevent myocardial micronecrosis following percutaneous coronary intervention? The ADELINE pilot trial adenosine Limit myocardial Necrosis. Heart 2002; 88: 293-295.

16. Lee CH, Low A, Tai BC, Co M, Chan My, Lim J, Lim YT, Tan HC pretreatment

with Intracoronary adenosine reduces the incidence of myonecrosis after non- urgent percutaneous Intervention: a prospective randomized study. European Heart Journal 2007; 28: 19-25.

17. Leesar MA, Stoddard M, Ahmed M, Broadbent J, Bolli R, Preconditioning of human myocardium with adenosine during coronary angioplasty. Circulation 1997; 95: 2500-2507.

18. Hata K, Whittaker P, Kloner RA, Pazyklenk K. Brief antecedent ischemia attenuates platelet- mediated thrombosis in damaged and stenotic canine coronary arteries: role of adenosine . Circulation 1998 ; 97:692-702.

19. Headrick JP, Hack B, Ashton KJ. Acute adenosinergic cardioprotection in ischaemic-reperfused hearts. Am J Physiol Heart Circ Physiol . 2003; 285: H 1797- H 1818.

20. Wilson RF, Wyche K, Christensen BV, Zimmer S, Laxson DD. Effects of Adenosine on human coronary arterial circulation. Circulation 1990;82: 1995-1606.

21. Hori M, Inoue M, Kitakaze M, Koretsune Y, Iwai K, Tamai J, Ito H, Kitabatake A sato T, Kamada T. Role of Adenosine in hyperemic response of coronary blood flow in mycroembolization. Am J Physiol 1986; 250: H509-H518.

22. Murtagh B, Higano S, Lennon R, Mathew V, Holmes DR, Jr, Erman A. Role of incremental doses fo intracoronary adenosine for fractional flow reserve assessment. Am Heart $J$ 2003; 146: 99-105. 